\title{
STRATEGI PENINGKATAN MUTU PENDIDIKAN MELALUI STANDARISASI TENAGA PENDIDIK
}

\author{
Al Amin 1 , Mei Indrawati ${ }^{2}$, C. Sri Hartati ${ }^{3}$ \\ Universitas Wijaya Putra Surabaya ${ }^{1,2,3}$ \\ Email: alaminarifinhusin@gmail.com
}

\begin{abstract}
ABSTRAK
Tujuan penelitian ini untuk mengetahui dan menganalisis kondisi dan strategi strategi peningkatan mutu pendidikan melalui standarisasi tenaga pendidik serta kendala dan solusinya di SMP Negeri 02 Rangsang Pesisir Kabupaten Kepulauan Meranti. Jenis penelitian ini adalah penelitian deskriptif dan pendekatan penelitian kualitatif. Teknik pengumpulan data dengan observasi, wawancara, dan dokumentasi. Informan dalam penelitian ini yaitu Guru SMP Negeri 02 Rangsang Pesisir Kabupaten Kepulauan Meranti yang berjumlah 5 orang. Analisis data dalam penelitian kualitatif antara lain Reduksi Data, Penyajian Data dan Conclusing Drawing/verification. Hasil penelitian menunjukkan bahwa mutu pendidikan yang meliputi kepemimpinan kepala sekolah, guru, siswa dan kurikulum yang diterapkan di sekolah sudah dilaksanakan dengan baik, Pembuatan program kerja kepala sekolah sudah didasarkan pada visi dan misi sekolah sehingga guru dapat meningkatkan pemahaman dan penguasaan kerja guru. Peningkatan kompetensi yang dimiliki guru dapat dilakukan dengan kegiatan pelatihan dan in house training serta MGMP (Musyawarah Guru Mata Pelajaran). Kurikulum harus disesuaikan dengan peraturan yang berlaku. Pembelajaran terkendala pandemi Covid 19, sehingga guru tidak dapat mengajar dengan baik, upaya yang dilakukan dengan melaksanakan membelajaran daring, membekali kompetensi guru dengan mengikutsertakan guru dalam seminar online atau pelatihan online pengajaran daring.
\end{abstract}

Kata kunci: Mutu pendidikan, standarisasi tenaga pendidik, strategi

\section{ABSTRACT}

The purpose of this study was to determine and analyze the conditions and strategies for improving the quality of education through standardization of educators as well as the obstacles and solutions. This type of research is descriptive research and qualitative research approach. Data collection techniques by observation, interviews, and documentation. The informants in this study were teachers of SMP Negeri 02 Rangsang Pesisir, Meranti Islands Regency, who opened 5 people. Data analysis in qualitative research includes data reduction, data presentation and drawing/verification of conclusions. The results of the study indicate that education which includes the leadership of principals, teachers, students and the curriculum applied in schools has been implemented well. The principal's work making program is based on the school's vision and mission so that teachers can improve teacher understanding and mastery. Improving the competence of teachers can be done through in-house training and training as well as Subject Teacher Conference. The curriculum must be adjusted to the applicable regulations. Learning is constrained by the Covid 19 pandemic, so teachers cannot teach well, efforts are made to carry out bold learning, equip teacher competencies by involving teachers in online seminars or online training for brave teaching.

Keywords: Quality of education, standardization of educators, strategy

\section{PENDAHULUAN}

Sebagai bentuk upaya dari Pemerintah menghadapi perkembangan yang ada saat ini dalam usahanya membuat berbagai perubahan dan melakukan pengembangan pada sistem pendidikan yang digunakan untuk mencapai peningkatan pendidikan yang bermutu. Agar mutu pendidikan dapat segera tercapai Pemerintah sudah menerapkan berbagai upaya, terutama pada ketersediaan tenaga pendidik yang 
memadai dan berkualitas yang tencantung pada Undang-Undang yang membahas mengenai Sistem Pendidikan Nasional (UU no. 20 th. 2003)

Pendidikan yang bermutu bisa diketahui dari hubungannya dengan apa yang dibutuhkan masyarakat, seperti siswa yang lulus bisa melanjutkan pendidikanya ke tingkat lebih lanjut atau untuk mendapatkan kelayakan pekerjaan, maupun memiliki kemampuan untuk mengatasi sebgala macam permasalahan yang terjadi di masyarakat. Pendidikan yang bermutu bisa diperlihatkan oleh kebermanfaatan lulusan di kehidupan bermasyarakat, berbangsa maupun bernegara. Sebagaian orang juga melakukan pengamatan pendidikan yang bermutu yang dilihatb dari seberapa besar keinginan seseorang untuk memperoleh ilmu pengatahuan.

Pendidikan di Indonesia saat ini mengacu pada Peraturan Pemerintah no. 32/2013 yang membahas mengenai Standar Nasional Pendidikan atau yang biasa kita kenal dengan singkatan (SNP), dimana isi dari kebijakan tersebut ada berbagai standar yang harus dicapai sekolah agar dikatakan memiliki pendidikan yang bermutu sebagai berikut: 1) kestandaran lulusan yang berkompeten, dimana standar ini meliputi perilaku siswa, pengetahuan yang dimiliki siswa serta keterampilan siswa. 2) kestandaran isi, dimana standar ini meliputi seberapa banyak marteri yang diberikan dan patokan standart konpetensi yang diterapkan. 3) kestandaran proses, dimana standar ini meliputi kegiatan belajar mengajar yang dilaksanakan. 4) kestandaran tenaga pendidik atau guru serta tenaga kependidikan atau staff yang ada di sekolah, dimana standar ini meliputi kelayakan jabatan dari karyawan atau staff yang dipekerjakan oleh sekolah dan pengajar atau guru. 5) kestandaran sarana dan prasarana, dimana standar ini meliputi kelas, lapangan olahraga, rumah ibadah, ruangan perpustakaan, ruangan laboratorium, ruangan praktik, sara bermain, tempat siswa untuk mengkreasikan bakat lain yang dapat mendukung pembelajaran, ketersediaan jaringan internet. 6) kestandaran dalam hal pengelolaan, dimana standar ini meliputi pembuatan rencaana, pelaksanaan kegiatan dan melakukan pengawasan. 7) Standar pembiayaan, dimana standar ini meliputi penjabaran mengenai berapa besar biaya operasional yang dikeluarkan dalam kegiatan belajr mengajar di sekolah. 8) Standar penilaian, dimana standar ini meliputi tata cara dalam melakukan penilaian hasil belajar siswa (PP no. 32 th. 2013). Kemudian pendapat Danim menjelaskan apabila sekolah ingin dikatakan mempunyai pendidikan yang bermutu harus setidaknya memiliki berbagai faktor, diantarnya pengelolaan kepemimpinan oleh kepala sekolah, tenaga pengajar, anak didik, penggunaan kurikulum, mempunyai partner kerjasama (Danim \& Khairil, 2014).

Dalam Peraturan Menteri Pendidikan Nasional Republik Indonesia Nomor 16 Tahun 2007 yang membahas mengenai kestandaran yang harus dimiliki oleh tenaga pendidik di sekolah tingkat SMP/MTs, minimal harus mempunyai kualifikasi akademik dengan minimal pendidikan terakhir S1 atau sarjana dan DIV atau Diploma empat dengan menyesuaiakan pada mata pelajaran yang ada di sekolah, dimana gelar tersebut dapat diperoleh tenaga pendidik dari program studi di Universitas atau Lembaga Pendidikan yang berputasi atau 
sudah terakreditasi oleh Kemenristek Dikti (Permendiknas no.16 th. 2007).

Peningkatan mutu pendidikan menjadi faktor penting dalam membangun pendidikan di Indonesia, karena dengan pendidikan yang bermutu, maka akan menghasilkan sumber daya manusia yang cerdas dan kompetitif. Peraturan Pemerintah No. 17 Tahun 2010 menjelaskan bahwa pendidik mempunyai tugas dan tanggung jawab sebagai pendidik professional mendidik, mengajar, membimbing, mengarahkan, melatih, menilai, mengevaluasi siswa, pendidikan dasar dan pendidikan menengah (PP no. 17 th. 2010).

Dalam menjalankan peningkatan mutu pendidikan melalui standar tenaga pendidik tentunya diperlukan strategi untuk mengatasi persoalan mutu pendidikan yang selaras dengan tuntutan perkembangan dan perubahan. Usaha peningkatan kualitas pendidikan bukan merupakan masalah yang sederhana, tetapi memerlukan penanganan yang baik dengan melibatkan berbagai pihak yang terkait. Mutu pendidikan bukan hanya terpusat pada pencapaian target kurikulum semata, akan tetapi menyangkut semua aspek yang secara langsung maupun tidak langsung turut menentukan terciptanya tenaga kependidikan yang berkualitas. Dengan demikian lembaga pendidikan diharuskan untuk menetapkan strategi pengembangan mutu guru yang bermuara pada peningkatan mutu sekolah. Ketercapaian mutu guru sangat bergantung pada kemampuan dan kecakapan serta kepemimpinan kepala sekolah.

Pelaksanaan standarisasi tenaga pendidik sedikitnya mencakup. a) Perencanaan Tenaga Pendidikan dan Kependidikan, Suatu kegiatan untuk menentukan kebutuhan tenaga kependidikan seperti guru, tata usaha, jumlah yang dibutuhkan dengan mempertimbangkan kualitasnya. b) Pengadaan Tenaga Kependidikan, Suatu program untuk memenuhi kebutuhan tenaga kependidikan suatu lembaga, jumlah yang dibutuhkan dengan mempertimbangkan kualitasnya. Agar dapat memperoleh tenaga pendidikan kependidikan sesuai dengan yang telah dibutuhkan, selanjutnya dilakukan kegiatan penyaringan calon tenaga pendidikan dan kependidikan sesuai kebutuhan. c) Pembinaan Dan Pengembangan Tenaga Kependidikan, Usaha-usaha untuk meningkatkan mutu serta efisiensi kerja seluruh tenaga yang berada dalam suatu unit organisasi baik tenaga menagerial. Tenaga teknis edukatif maupun tenaga tata usaha yang sesuai dengan standart yang ditetapkan. d) menerapkan sistem promosi bagi tenaga pendidikan dan kependidikan, dimana sistem ini pihak sekolah berkoordinasi dengan Dinas Pendidikan Rangsang Pesisir Kabupaten Kepulauan Meranti (Sahertian, 2015).

Penelitian yang dilaksanakan kali ini tentunya mempunyai tujuan yang akan dicapai diantaranya untuk mengetahui serta menganalisa kondisi mutu pendidikan di SMP Negeri 02 Rangsang Pesisir Kabupaten Kepulauan Meranti. Untuk mengetahui serta menganalisa penerapan strategi yang dilakukan supaya Mutu pendidikan dapat memelalui standarisasi tenaga pendidik di SMP Negeri 02 Rangsang Pesisir Kabupaten Kepulauan Meranti. Untuk mengetahui dan menganalisis kendala dalam melaksanakan strategi peningkatan mutu pendidikan melalui standarisasi tenaga pendidik dam solusinya di SMP Negeri 02 
Jurnal Santiaji Pendidikan, Volume 11, Nomor 3, September 2021 ISSN 2087-9016, e-ISSN 2685-4694

Rangsang Pesisir Kabupaten Kepulauan Meranti.

\section{METODE PENELITIAN}

Penelitian deskriptif digunakan sebagai jenis dari penelitian ini, hal ini dikarenakan penelitian ini mempunyai tujuan untuk mengetahui dengan melakukan gambaran yang tersususan berdasarkan fakta-fakta yang terjadi di lapangan. Peneliti nantinya akan mencari data untuk menggambarkan strategi yang diterapkan sebagai upayanya dalam peningkatan mutu pendidikan melalui standarisasi tenaga pendidik di SMP Negeri 02 Rangsang Pesisir Kabupaten Kepulauan Meranti dengan memerlukan pendeskripsian data yang telah ditemukan, selain itu yang memerlukan observasi pada setiap prosedur penyampaian kegitan pembelajaran di sekolah untuk mencapai kefektifan dalam belajar.

Sedangkan penelitian kualitatif digunakan sebagai pendekatan dari pelaksanaan penelitian kali ini. Pendekatan tersebut dipilih karena pada penelitian ini disajikan dalam bentuk uraian kata-kata yang tidak membahas dalam bentuk angka-angka (Moleong, 2017).

Adapun data dalam penelitian kali ini dapat dikumkulkan melalui berbagai teknik diantaranya : a) interview atau yang biasa disebut dengan wawancara, dimana adalanya pertemuan tatap muka antara peneliti dan informan melakukan pembicaraaan dengan format pertanyaan yang sudah ditentukan sebelumnya (Esterberg dalam Sugiyono, 2017). Informan pada penelitian kali ini meliputi Guru SMP Negeri 02 Rangsang Pesisir Kabupaten Kepulauan Meranti yang berjumlah 5 orang. b) Dokumentasi. Merupakan data pendudukung untuk melengkapi hasil dari wawancara kepada informan yang berasal dari berbagai dokumen yang ada di sekolah (Moleong, 2017).

Setelah semua data terkumpul, langkah selanjutnya dalam metode penelitian yang berpendekatan kualitatif kali ini dengan melakukan analisa yang dapat dibedakan menjadi 3 macam Data Reduction (Reduksi Data), Data Display (Penyajian Data), dan Conclusing Drawing/ verification. Berikut adalah gambar dari analisis data dan model interaktif (Sugiyono, 2017):

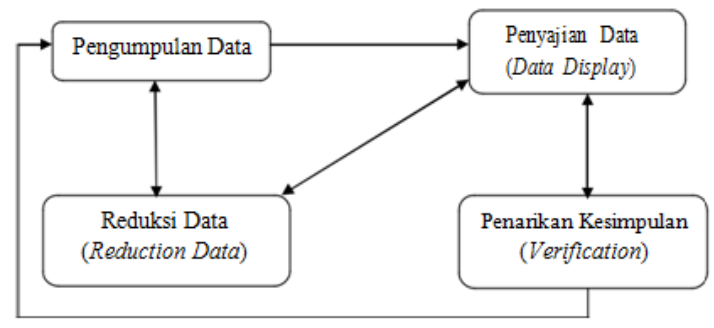

Gambar 1. Model Analisis Data

\section{HASIL DAN PEMBAHASAN}

Peningkatan mutu pendidikan merupakan menjadi factor penting dalam membangun pendidikan di Indonesia, karena dengan pendidikan yang bermutu, maka akan menghasilkan sumber daya manusia yang cerdas dan kompetitif. Dengan adanya Peraturan Pemerintah (PP) No 19 Tahun 2005 tentang Standar Nasional Pendidikan (SNP) untuk mewujudkan program peningkatan mutu pendidikan yang berkelanjutan, dimana terdapat beberapa ketentuan-ketentuan yang membahan syarat sistem pendidikan minimun yang diterapkan pada semua wilayah di Indonesia. Mutu pendidikan dalam penelitian ini dijelaskan dalam kepemimpinan kepala sekolah, guru, siswa dan kurikulum yang diterapkan di SMP Negeri 02 Rangsang Pesisir Kabupaten Kepulauan Meranti. 
Kepemimpinan kepala sekolah SMP Negeri 02 Rangsang Pesisir Kabupaten Kepulauan Meranti sudah dijalankan dengan sangat baik (PP no. 19 th. 2005). Selain itu program kerja yang dilaksanakan kepala sekolah sudah berdasar pada visi dan misi sekolah yang meliputi program jangka pendek, menengah maupun jangka panjang sehingga dapat terlaksana dengan baik. Kemudian pelayanan yang diberikan kepala sekola kepada semua guru sudah dilakukan dengan maksimal dengan selalu memberikan himbauan dan penyuluhan kepada guru sehingga guru dapat meningkatkan pemahaman dan penguasaan kerja guru sehingga tercipta kerjasama yang baik. Meskipun secara keseluruhan sudah baik akan tetapi masih perlu adanya peningkatan demi kesempurnaan program kerja periode yang akan datang agar mutu pendidikan di sekolah juga semakin meningkat.

Guru di SMP Negeri 02 Rangsang Pesisir Kabupaten Kepulauan Meranti sudah terlibat aktif dalam semua kegiatan sekolah, termasuk kegiatan seminar, lokakarya atau pelatihan dalam rangka peningkatan kompetensi dan profesionalisme guru diantaranya mampu menyusun perangkat pembelajaran dengan baik dan mampu mengajar dengan berbagai metode dan materi pembelajaran yang beragam yang dapat disesuiakan dengan kondisi siswa. Selain itu guru mengetahui kompetensinya mengenai pemahaman tentang peserta didik, pemahaman tentang pendidik dan pembelajaran, pemahaman tentang kurikulum sekolah, perancangan pembelajaran, pelaksanaan pembelajaran, evaluasi proses dan hasil belajar, peningkatan kompetensi yang dimiliki guru dapat dilakukan dengan kegiatan pelatihan dan in house training dan MGMP. Hasil ini sesuai dengan penelitian yang dilakukan Khrisnamurti yang memberikan penjelasan terkait dengan strategi yang ditepakan pimpinan di sekolah dalam upayahnya standar pendidik serta tenaga kependidikan dapat ditingkatkan dengan berbagai tahap sebagai bentuk terjaganya konsistensi tenaga pendidik, kepala sekolah selalu mengarahkan guru agar melakukan pelatihan-pelatihan diklat dan MGMP (Khrisnamurti, 2019).

Hampir semua siswa di SMP Negeri 02 Rangsang Pesisir Kabupaten Kepulauan Meranti sudah nilainya sudah di atas KKM (Kriteria Ketuntasan Minimal) lebih tepatnya 95\% siswa sudah memperoleh nilai yang di atas KKM selain itu itu beberapa siswa juga turut serta pada Olimpiade Olahraga Siswa Nasional Jenjang Sekolah Menengah Pertama (O2SN-SMP) meraih juara 3, Olimpiade Sains Nasional (OSN) meraih juara 3 dan lomba cerpen tingkat Kabupaten.

Penyusunan kurikulum di SMP Negeri 02 Rangsang Pesisir berdasarkan rapat dengan majelis guru dan komite sekolah dan Sekolah juga sudah menjalankan semua kurikulum yang telah ditetapkan. Kurikulum yang dijalankan saat ini sudah sesuai dengan peraturan yang berlaku dan dapat memudahkan guru dalam mewujudkan tujuan pembelajaran. Kurikulum sudah tersusun dengan baik dan sudah benjalan dengan kondusif serta sudah teradministrasi dengan baik sehingga dapat membuat perubahan dan penambahan ilmu guru serta menjadi tertib administrasi dan dapat membuat guru menjadi lebih mudah dalam melaksanakan proses belajar mengajar di kelas. Hasil penelitian ini mendukung 
penelitian yang dilakukan oleh Etisnawati dengan menerapkan yang metode mengajar secara efektif, menata setting kelas sebelum pembelajaran dimulai, mengenali minat dan kemampuan siswa, dan mengevaluasi pembelajaran (Etisnawati, 2020).

Dalam upaya mewujudkan tujuan pembangunan nasional guru mempunyai peran yang sangat strategis, sehingga perlu dikembangkan sebagai tenaga profesi yang bermanfaat dan professional. Peraturan Pemerintah No. 17 Tahun 2010 menjelaskan bahwa pendidik mempunyai tugas dan tanggung jawab sebagai pendidik professional mendidik, mengajar, membimbing, mengarahkan, melatih, menilai, mengevaluasi siswa. Sedangkan standarisasi tenaga pendidik sedikitnya mencakup perencanaan tenaga pendidik, pengadaan tenaga pendidik, pembinaan dan pengembangan tenaga pendidik, promosi dan mutasi tenaga Pendidik (Peraturan Pemerintah No. 17 Tahun 2010 Tentang Pengelolaan Dan Penyelenggaraan Pendidikan, 2010). Kebutuhan tenaga pendidik di SMP Negeri 02 Rangsang Pesisir Kabupaten Kepulauan Meranti dengan melakukan penyesuaian berdasarkan jumlah kebutuhan mata pelajaran. Secara jumlah guru yang ada di sekolah sudah mencukupi tetapi secara kualitas masih ada beberapa yang masih perlu ditingkatkan. Oleh karena itu kebutuhan guru dapat dikatakan sudah mencukupi dan tidak diperlukan penambahan ataupun melakukan pengurangan karena kebutuhan guru sudah didasarkan pada kebutuhan mata pelajaran

Promosi kenaikan bagi tenaga pendidik di SMP Negeri 02 Rangsang Pesisir Kabupaten Kepulauan Meranti dapat menjadikan guru lebih giat dalam melaksanakan tugasnya. Promosi dapat dilakukan apabila guru yang sudah memenuhi kriteria seperti pencapai prestasi dan kinerjanya yang tinggi akan dipromosikan ke jabatan yang lebih tinggi dan disampaikan secara terbuka. Misalkan semula yang awalnya hanya guru biasa kemudian menjadi kepala program keahlian tertentu atau menjabat sebagai wakil kepala sekolah. Apabila ada guru ingin melakukan mutasi dapat diajukan dengan permohonan sendiri. Misalkan guru tersebut diterima sebagai guru CPNS di sekolah lain atau pindah domisili yang mengharuskan pindah tempat kerja dapat mengajukan secara pribadi.

Meskipun secara garis besar mutu pendidikan sudah baik akan tetapi masih ditemukan beberapa kendala di SMP Negeri 02 Rangsang Pesisir Kabupaten Kepulauan Meranti diantaranya: 1) Pembelajaran terkendala pandemi Covid 19, sehingga guru tidak dapat mentransfer pengetahuan dengan baik kepada siswa. 2) Guru mengalami kesulitan dalam memahami kondisi siswa karena tidak dapat berinteraksi secara langsung. 3) Guru tidak memiliki motivasi untuk mengembangkan kemampuannya. 4) Guru dituntut untuk membuat laporan kinerja guru secara online. 5) Ketidakhadiran siswa dalam kegiatan belajar menagajar. 6) pengumpulan tugas siswa tidak tepat waktu.

Upaya dalam mengatasi kendala peningkatkan mutu pendidikan melalui standarisasi tenaga pendidik di SMP Negeri 02 Rangsang Pesisir Kabupaten Kepulauan Merantib adalah sebagai berikut: 1) Melaksanakan pembelajaran secara daring. 2) Pembekalan kepada guru dengan kompetensi pengajaran daring agar pembelajaran dapat dilakukan dengan baik. 3) Mengikutsertakan guru dalam 
Jurnal Santiaji Pendidikan, Volume 11, Nomor 3, September 2021 ISSN 2087-9016, e-ISSN 2685-4694

seminar online atau pelatihan online agar guru dapat melakukan pembelajaran daring dengan lebih optimal sehingga pembelajaran yang lebih menarik agar mudah dipahami oleh siswa.

\section{PENUTUP}

\section{Kesimpulan}

Berdasarkan pada hasil penelitian, maka penelitian dapat membuat kesimpulan bahwa mutu pendidikan dalam penelitian ini dijelaskan dalam kepemimpinan kepala sekolah, guru, siswa dan kurikulum yang diterapkan di SMP Negeri 02 Rangsang Pesisir Kabupaten Kepulauan Meranti sudah dilaksanakan dengan baik, meskipun demikian masih terdapat beberpa hal yang perlu ditingkatkan.

Pembuatan program kerja yang dilaksanakan kepala sekolah didasarkan pada visi dan misi sekolah yang meliputi program jangka pendek, menengah maupun jangka panjang kemudian memberikan himbauan dan penyuluhan kepada guru sehingga guru dapat meningkatkan pemahaman dan penguasaan kerja guru sehingga tercipta kerjasama yang baik. Peningkatan kompetensi yang dimiliki guru dapat dilakukan dengan kegiatan pelatihan dan in house training dan MGMP. Kurikulum harus disesuaikan dengan peraturan yang berlaku sehingga dapat berjalan dengan kondusif dan diadministrasi dengan baik sehingga dapat membuat guru menjadi lebih mudah dalam melaksanakan proses belajar mengajar di kelas.

Pembelajaran terkendala pandemi Covid 19, sehingga guru tidak dapat mentransfer pengetahuan dengan baik kepada siswa, Guru mengalami kesulitan dalam memahami kondisi siswa karena tidak dapat berinteraksi secara langsung.
Upaya yang dilakukan dengan melaksanakan membelajaran secara daring, membekali guru dengan kompetensi pengajaran daring dengan mengikutsertakan guru dalam seminar atau pelatihan online.

\section{Saran}

Dari apa yang sudah disimpulkan tersebut di atas, maka peneliti bisa bersaran diantaranya memberikan himbauan dan penyuluhan kepada guru sehingga guru dapat meningkatkan pemahaman dan penguasaan kerja guru. Selanjutnya, pengadministrasian kurikulum perlu dilakukan dengan baik sehingga dapat mempermudah guru dalam melaksanakan proses belajar mengajar. Selain itu, peningkatan pelibatan guru dalam semua kegiatan yang ada di sekolah sekolah perlu dilakukan. Hal itu terutama pada kegiatan seminar, atau pelatihan dalam rangka peningkatan kompetensi dan profesionalisme guru dalam pembeljaran daring agar guru dapat melakukan pembelajaran dengan lebih optimal sehingga pembelajaran yang lebih menarik agar mudah dipahami oleh siswa

\section{DAFTAR PUSTAKA}

Danim, S., \& Khairil. (2014). Profesi Kependidikan. Alfabeta.

Etisnawati. (2020). Strategi Kepala Sekolah Dalam Peningkatan Mutu Tenaga Pendidik. Jurnal EDUCATIO (Jurnal Pendidikan Indonesia), 6(1), 13-18. https://doi.org/10.36671/andragogi.v $2 \mathrm{i} 2.99$

Khrisnamurti, D. A. (2019). Strategi Kepala Sekolah Dalam Meningkatkan Standar Pendidik dan Tenaga Kependidikan di SMA Negeri 6 Samarinda. Jurnal Penelitian Pendidikan \& Pembelajaran, 6(3), 63-71. 
Jurnal Santiaji Pendidikan, Volume 11, Nomor 3, September 2021 ISSN 2087-9016, e-ISSN 2685-4694

https://doi.org/10.31227/osf.io/r95vn

Moleong, L. J. (2017). Metode Penelitian

Kualitatif. PT. Remaja Rosdakarya Offset.

Peraturan Menteri Pendidikan Nasional Republik Indonesia Nomor 16 Tahun 2007 Tentang Standar Kualifikasi Akademik dan Kompetensi Guru.

Peraturan Pemerintah (PP) No 19 Tahun 2005 tentang Standar Nasional Pendidikan (SNP).

Peraturan Pemerintah No. 17 Tahun 2010

Tentang Pengelolaan dan

Penyelenggaraan Pendidikan, (2010).

Peraturan Pemerintah Republik Indonesia Nomor 32 Tahun 2013 Tentang perubahan atas Peraturan Pemerintah Nomor 19 Tahun 2005 Tentang Standar Nasional Pendidikan (SNP).

Sahertian, A. P. (2015). Konsep Dasar dan Teknik Supervisi. Rineka Cipta.

Sugiyono. (2017). Metode Penelitian Kuantitatif, Kualitatif, dan $R \& D$. Alfabeta.

Undang-Undang Nomor 20 Tahun 2003 Tentang Sistem Pendidikan Nasional. 